\title{
3 The Custody of Spiritual Education in Ireland
}

\author{
James O'Higgins Norman and \\ Caroline Renehan
}

$\begin{array}{lr}\text { INTRODUCTION } & 1\end{array}$

This chapter will explore the historical and sociological context of spiritual education in the Republic of Ireland. It will show how spirituality in education in Ireland has mostly been characterised by Jansenistic themes such as original sin, human depravity and the necessity of divine grace. Consequently, spirituality in education in Ireland has mostly been associated with Religious Education with an emphasis, although not exclusively, on cognitive learning. This understanding of spirituality, particularly with the development of nonfaith-based schools, is only beginning to be replaced by a more holistic view of the person in which the spirit does not have to be identified with religious knowledge. In this chapter we understand spirituality as a fundamental concept that defines humanity as distinct from all other living things. It has to do with our relationship with self, with all other people, with the environment and with the transcendent. A person who has achieved some level of integration between all of these relationships in his or her life then can be said to be spiritual. Human spirituality is transformational in that it takes one out of one's self to connect with and be concerned for everything else outside of self. We can recognise people's spirituality in their capacity for love, compassion, patience, tolerance, forgiveness, happiness, generosity, responsibility and harmony. Spirituality is nourished by connecting with the transcendent but not in any abstract or theoretical way. For some this connection will be maintained through prayer while for others it is achieved through quality relationships that raise us up and out of ourselves. In this sense, to recognise the spiritual in oneself is to challenge oneself and the quality of the relationships that contribute to who we are and how we live.

HISTORICAL CONTEXT OF SPIRITUAL EDUCATION IN IRELAND 29

The close association between spirituality and academic learning in Ireland 31 is well expressed in the characterisation of Ireland as the 'Land of Saints 32 and Scholars'. It seems that early monastic schools which were founded 33 


\section{James O'Higgins Norman and Caroline Renehan}

in the 6th century saw no conflict between their love of God and love of learning. It was through the influence of the monastic schools in the 8th and 9th centuries that schools and colleges spread rapidly all over the country (Raftery, 2009). In these schools, secular as well as religious (ecclesiastical) learning was catered for. Their subjects included divinity, the scriptures, the classics, literature and science. In those great seminaries, religion in education appeared to sit seamlessly alongside education in secular subjects. As time progressed, religion and education became intertwined between love of God and love of learning. In the words of Raftery, "the history of the labyrinthine connections between the churches, the State and schooling in Ireland . . dates back at least to the sixth century" (2009, p. 9). Nor were all of their students destined to enter the Church, for a large proportion of them were the sons of chiefs and kings preparing to take their place in civil or military life (Hyland \& Milne, 1987).

A sense of the seamlessness between life and education, education in religion and other disciplines in the monasteries was a feature of early education in Ireland in monasteries such as that founded by Colmcille (or Columba), the son of a Donegal Chief at Iona who facilitated the spreading of Christianity to the Orkney and Shetland Islands in Scotland and also in northern England. Another, Columbanus born in Co Meath, emerged from the austerity of Celtic Christianity and became one of the most outstanding sources of cultural, educational and spiritual renewal in Europe. Travelling from Ireland to Italy, he and his followers established numerous monasteries in France, Switzerland, Germany, Austria and Italy, which became strongholds of safety, education, employment and culture amidst the turmoil of the so-called 'Dark Ages'. These monasteries continued for centuries to serve both religious and social life in Ireland at one and the same time. The typical monastery was like a little village of huts and small houses surrounding the central church. The Irish Church at this stage was largely independent of the structure and influence of Rome and hence developed spirituality along its own cultural lines.

This association between religion and learning continued and became a function of the colonisation of Ireland. Dunn argues that from "the early days of the Tudor conquest, schooling in Ireland became intimately bound up with the process of colonisation and with the consequent ascendancy of the English language" (1988, p. 95). In the same way, education in religion became part of Tudor policy in respect of the Church of England's Reform tradition. According to Glendenning (2007), the Tudors were the first to legalise the promotion of the religious principles of the Reformation. Following the Battle of the Boyne (1690), the Protestant ascendancy in Ireland came increasingly to the fore dominating education in religion through the Reform tradition. Tudor policies were instrumental in spreading the influences of the Reformation for approximately the next century and a half. Throughout the 17 th and 18 th centuries, Glendenning 
recounts that "England relied upon a comprehensive series of repressive legislative measures, (the Penal Laws), to implement its policies in Ireland thereby affecting four crucial areas of Catholic life: property; religion; personal disabilities and education" (2007, p. 13). Education in religion delivered from the perspective of Catholic Christianity was particularly adversely affected by these laws as Catholic teachers were forbidden either from teaching or running a school. Any teacher or member of the clergy found not adhering to these laws received punitive treatment mostly in the form of heavy fines (Glendenning, 2007). Of particular importance was the Education Act (1695). ${ }^{1}$ This forbade Catholics from sending their children to Catholic education centres in countries such as Spain and France (Rafferty, 2009, p. 11). Hyland and Milne explain that the Act specifically wanted to protect children from being educated anywhere by "any Jesuit, seminary priest, friar, monk, or other popish person" (1987, p. 47). The effect of the Penal Laws in Ireland was to embed deep in the psyche of the Roman Catholic majority population a continued identification of learning and religion as one. It is important to note that throughout the Penal Law period in Ireland, Church leaders continued to emphasise that spiritual development was achieved through religious knowledge. As early as 1730, the Catholic diocesan statutes of Dublin required every "parish priest to have a schoolmaster in his parish to teach Catholic doctrine" (McCracken, 1986, p. 95). These men kept a careful watch on education in religion. Corish observes that the hedge schoolmaster "was expected to teach Catechism. ... If he did not he was carpeted; if he could not he was instructed" (Corish, 1981, p. 102).

This concern for the teaching of Catholic doctrine within schools continued and was well established by the final lifting of the Penal Laws with the Relief Act (1829) and the introduction of national schools from 1831 onwards. These new primary schools were developed on the recommendations of the then Chief Secretary for Ireland Edward Stanley and addressed to the Duke of Leinster. In the so-called 'Stanley Letter' he recommends that these new schools could

afford combined literary and moral, and separate religious instruction, to children of all persuasions, as far as possible, in the same school, upon the fundamental principle that no attempt shall be made to interfere with the peculiar religious tenets of any description of Christian pupil. (Stanley Letter, 1831) 


\section{James O'Higgins Norman and Caroline Renehan}

Of all parts of a school curriculum Religious Instruction is by far the most important, as its subject matter, God's honour and service, includes the proper use of all man's faculties, and affords the most powerful inducements to their proper use. Religious Instruction is, therefore, a fundamental part of the school course, and a religious spirit should inform and vivify the whole work of the school. (Rule 68)

The centrality of Religious Education thus was taken as a given emanating from (i) The Constitution (1922), (ii) The Constitution (1937) and the Rules for National Schools (1965), and it was not until the Education Act (1998) that we find the first signs of divergence between spirituality and religious education or religion. The Act states that the purpose of the school is to

promote the moral, spiritual, social and personal development of students and provide health education for them, in consultation with their parents, having regard to the characteristic spirit of the school. (Section 9.d)

This failure of the education system in Ireland until recently to acknowledge that spiritual development and Religious Education are not synonymous means that we are only now beginning to consider what the implications of this reality are for children, families and wider society.

\section{CURRENT ANALYSIS OF SPIRITUALITY IN EDUCATION}

Historically modern Irish society has emerged out of a postcolonial context in which for centuries the Crown and the churches had strongly influenced, if not controlled, most aspects of people's lives. In fact, the relationship between these authorities and the individual permeated all aspects of life, even aspects that we might consider to be private such as family life, sexuality and spirituality. An example of this can be seen from the late 19th century onwards in the growth of institutions established to reform or rehabilitate women. These so-called 'Magdalene' asylums and laundries increasingly took on the character and punitive ethos of prisons where inmates were expected to do hard labour and work long hours unpaid (McAleese, 2013). In the eyes of the churches and society the women who were sent to these institutions were removed from family, community and society because they had sinned sexually or to ensure that they would be protected from impurity. They were often viewed as second-class people who had failed and this extended to the children they bore. Those who managed these institutions understood their role as agents of church and society ensuring that neither the women nor the children in their care would be further associated with their families or communities through any scandal. To a considerable extent, it could be said that these institutions operated through an 
ethos that was paternalistic and punitive towards those who were viewed as sinners and the offspring of sinners resulting in a spirituality characterised by correction and external rituals of piety.

With the emergence of the Irish Free State in 1922 the newly formed government was mostly composed of middle class Catholics who had come from landed and professional families, and as such were more inclined to value and maintain the status quo where religious and spiritual education were concerned. In that context, the spiritual education of those who lived in Magdalene institutions and those who attended mainstream schools remained unchanged. It could be argued that the Jansenistic ethos that permeated Irish educational institutions was strengthened through its validation by the newly formed organs of the state. Recently exposed scandals and crimes of a physical and sexual nature carried out against children in the care of the state and the churches have revealed that a particular view of childhood had dominated educational provision in Ireland from the 18th century up to the end of the 20th century when the last so called 'Magdalene laundry' closed in 1996. There is little evidence to suggest that prior to the late 20th century the collective consciousness of Irish society considered spiritual education among children to be anything other than serving the purpose of overcoming original sin and depravity. The publication of the Ryan Report in 2009 and the Murphy Report, also in 2009, for example, reveal that children in general were not believed to have the same rights as adults and those who had been born outside of wedlock or who came from poverty were viewed as a burden to the state and an outrageous challenge to the societal norms and mores that were officially and informally sanctioned at the time.

The symbiotic relationship established between churches and the state in education continues to the present day and while it may have been acceptable to argue in the past that the status quo in Irish schooling reflected the values of the majority of the population, the need for greater diversity in the provision of Irish schooling has become apparent to both institutions. Recent deliberations between churches and state in the past decade or so now show that considerable progress is being made in understanding the relationship between a religious and nonreligious school-based ethos, particularly at primary school level (Drumm, 1997; Coolahan, Hussey \& Kilfeather, 2012). In this context, it is therefore timely for those interested in the spiritual education of the young to revisit the essential dynamic at play between spiritual and religious education and to give equal and specific attention to these essential aspects of human life.

For at least a century educators have argued that a gap exists between what $\quad 44$ is taught in schools and what a person needs to function fully and to be 45 


\section{James O'Higgins Norman and Caroline Renehan}

successful in society (Dewey, 1916/1966; Lindeman, 1926; Coyle, 1947; Pring, 2007). The same can be said in relation to spirituality as, quite often, schools equate spiritual development solely with religious education and adherence to officially sanctioned forms of spirituality to the detriment of diversity (Watson, 2000). Too often, schools have focused largely on scholastic development to the extent that the interpersonal skills required for a full spiritual development are often neglected. Almost one hundred years ago John Dewey (1916/1966) argued that there is an intimate connection between education and the quality of societies. He claimed that democratic societies could only continue to exist if schools promoted exploration and growth rather then repressing expression and creativity. Progressive educationalists have identified the qualities that are needed to manage life intelligently and to participate in society, namely, critical thinking, problem solving, communicating and collaboration (Dewey, 1916/1966; Lindeman, 1926; Coyle, 1947; Williams, 2007), all of which can be promoted through spiritual development.

Educational settings have been found not always to be the most suitable environments for this type of transformational process to be experienced. Apart from a strong focus on scholastic achievement, modern schools often reflect what Bauman (1991) refers to as society's 'solid' form and attempt to remove all unknowns and uncertainties in the educational process. A modern concern with instrumental and organisational goals in schooling has resulted in other aspects of education, such as spiritual development, receiving less attention in many schools in Ireland. These somewhat intangible aspects of a school's remit include cultural activities, the formation of character, the cultivation of attitudes, the transmission of values and freedom of thought, all of which are important for spiritual development. While these expressive goals are important as a source of cohesion and unity within a school as well as providing the foundations of democracy and collaboration in wider society, they are also important for an individual child's spiritual development. In fact, a lack of these qualities can contribute to a society where citizens are competitive, individualistic and overly concerned with material wealth resulting in a lack of concern for others.

In response to this historical problem of goal displacement where spiritual development is concerned, the new Primary School Curriculum (1999) in Ireland was developed to integrate spirituality across all aspects of children's learning. The inclusion of spiritual development is explicitly related to learning that includes religious education but is not limited to that syllabus:

The importance that the curriculum attributes to the child's spiritual development is expressed through the breadth of learning experiences the curriculum offers, through the inclusion of religious education as one of the areas of the curriculum, and through the child's engagement with the aesthetic and affective domains of learning. (Primary School Curriculum, 1999, p. 27) 
Arising from this particular vision of schooling, it is intended that children will understand and learn how to live life with concern for others, to solve issues related to global perspectives, to contribute to society and experience a sense of belonging to that society. While there is no shortage of evidence for the spiritual element in approaches to faith formation and development at both primary and post-primary levels in Religious Education classes, particularly in faith-run schools, the spirituality element is also evident in non-class situations such as prayer services, sacramental preparation (at primary), class Masses, beginning and end of year school Masses and Advent, Lent, Easter liturgies, reconciliation services, special services for the bereaved, carol services, prayers at the beginning of class and ecumenical and interreligious services, all of which can be spiritually uplifting. These are found not only in faith-run schools but also in multidenominational schools, The relationship between Religious Education and spirituality is accepted without question and they are by and large recognised as synonymous with one another. In these circumstances the Religious Education teacher is given not only an academic remit but also a spiritual one, albeit faith based. In many schools in the Republic of Ireland, in respect of developing the spiritual education of the child, the Chaplain and the Religious Education teacher share the responsibility between them. Nonetheless, there is still a great deal more work to be done given the heritage of unilateral restraint imposed on schools by churches, state and society in the country's past.

For too many young people in Ireland in the past, teaching and learning 28 relationships at school were characterised by violence and tension which $\quad 29$ was experienced and accepted as the norm by school authorities, parents 30 and wider society. Punitive approaches to classroom management and to 31 pupil learning undermined the possibility of a young person developing the 32 balance or integration that is the hallmark of spirituality. Martin explains 33 that "children living in an atmosphere of fear and tension are unlikely to 34 be psychologically available to engage in life in school" (2006, section 3, 35 paragraph 8) and as such spiritual development was difficult. 36

Recent research in Ireland found that 84\% of admissions to psychiatric 37 hospitals were children aged 15-17 years (Hanfin et al., 2008) while a pre- 38 vious study revealed that $15.6 \%$ of pupils aged $12-15$ years had a current 39 psychiatric disorder (Lynch, Mills, Daly, and Fitzpatrick, 2006). Research 40 in other countries such as Norway, France and Finland found that about 41 $12-15 \%$ of children and young persons aged from 10 to 19 years self-re- 42 ported mental health problems (Van Roy, Grøholt B., Heyerdahl, S., and 43 Clench-Aas J., 2006; Fombonne, 1998; Puura et al., 1998) with a higher 44 prevalence of $19 \%$ of young people in this age group in Germany suffering 45 


\section{James O'Higgins Norman and Caroline Renehan}

from anxiety disorders and 18\% from depression (Essau, Karpinski, Petermann, and Conradt., 1998). The importance of social cohesion and relationships, as well as the ability to be involved in decision-making and a sense of belonging and safety in different situations, has been highlighted as crucial in promoting wellbeing among young people (Morrow, 2000; World Health Organisation Regional Office for Europe, 2007) and cannot be ignored by schools in relation to spiritual development.

In order to respond to this problem, schools will have to consider to a greater extent the employment of empathetic strategies that might be useful to help children and young persons to achieve an integration of self. Furthermore, schools will need to continue to find ways that help young people, despite their personal struggles, to transcend their own psychological, spiritual and material wounds and to connect with the needs of their brothers and sisters in the global family. Schools are now increasingly looking for praxis-orientated approaches that will offer greater opportunity for young people to engage courageously with their own desires for healing and wholeness. A praxis approach synthesises our thoughts, our intentions, our judgements and our actions. At a practical level, it helps us to serve others, to rediscover the goodness of life and commits us to acts of kindness and love. Specifically, praxis calls upon us to remove any such barriers that keep our fellow human beings marginalised. Without it, any ethical, moral or spiritual system has a lesser chance of understanding the vulnerability or the fragility of the human condition. Educators are seeking to respond to these deeper issues of the human heart and to be able to help young people to question issues relating to belonging and loneliness, good and evil, peace and division, healing and suffering, meaning and meaninglessness, hope and despair, love and apathy, justice and injustice, freedom and repression and, ultimately, life and death questions. Ultimately, it is through the development of an integrated life, achieved through positive relationships, that a young person will achieve wellbeing, which includes spiritual wholeness. This should challenge young people to grow in nonviolence, work for human rights, be merciful and seek liberation of all, and most of all deepen their relationship with God, others, the environment and self (O'Higgins Norman and Hall, 2011) . These questions are rooted in an essential pastoral perspective when teachers, chaplains, guidance counsellors and school leaders pass over from clinical definitions of emotional disturbance and engage young people to envision realistic alternatives. Such alternatives include the healing narratives of the relationships between the material and the spiritual realms of existence, between spirituality and education, between spirituality and religious education. In this environment, young people can move from the narratives of the battered and the broken to inclusiveness and wholeness, from the abyss of emptiness to the hope of fullness and fulfilment.

Sometimes, simple mechanisms can be used by teachers to promote spiritual development among their students, but it is also essential that 
those who 'teach' spiritual development have experienced spiritual growth themselves. For example, Miller and Athan (2007) provide an example of how working with graduate student teachers enabled them in turn to become conduits for spiritual development among their pupils. This was achieved by engaging student teachers in a programme in which they were encouraged to bring "private, raw, neglected and often discredited stories" from their own personal experience to be explored in a supportive encounter with their teacher educators (2007, p. 21). Miller and Athan outline a four-stage approach that can be adapted into most classroom contexts and used as a basis for spiritual development. The process is built on the work of Freire (1993) and the premise that educators redefine the traditional teacher/learner relationship by 'authorising' the student as a partner in a democratic process of education based less on the belief that the teacher and institution are the source of knowledge and more on the belief that the learner is empowered to learn and grow as a human person. The ultimate aim of the process outlined by Miller and Athan is to reveal the spiritual dimension of life as significant and evocative, equipping students to cope with the high points and challenges of their life journeys (2007, p. 31).

The role of empathy in promoting spiritual development is also extremely important and has been highlighted in research (Zembylas, 2012; Cooper, 2010; de Souza and McLean, 2012). However, the work of teachers is continually expanding and becoming more pressurised as schools and curricula are increasingly identified as the means by which society expects to select young people for the labour market and by which competent citizens will be developed. Research in Ireland by Boldt (2000) and more recently in the UK by Cooper (2010) on this issue found that while teachers deeply desire to play a more empathetic and caring role in the lives of their pupils a number of factors mitigate against them being able to achieve their pastoral goals. A lack of time, a fragmented and rigid curriculum, bureaucracy of modern education and the large number of pupils all work to undermine teachers' ability to be empathetic and caring in schools. This has serious consequences for spiritual education, and in Ireland the presence of a terminal examination in post-primary schools, the results of which are used to select students for places in higher education, also puts additional pressure on teachers thus reducing the time and space available to develop and model personal and empathetic relationships with their pupils.

2

3

4

5

6

7

8

9

10

11

12

13

14

15

16

17

18

19

20

21

22

23

24

25

26

27

28

29

30

31

32

33

34

35

36

37

38

39

40

$\begin{array}{ll}\text { CONCLUSION } & 41\end{array}$

42

It is clear that the people of Ireland have since ancient times placed a high 43 value on learning. For much of the history of Ireland learning and spiritual- 44 ity have been understood as synonymous activities, albeit that the spiritual $\quad 45$ 


\section{James O'Higgins Norman and Caroline Renehan}

aspect of learning has been overidentified with the acquisition of religious knowledge, thence Religious Education continues to be a core activity of modern primary and post-primary schooling in Ireland.

It is only since the introduction of the Education Act (1998) that there has been official recognition by the state that spiritual development and Religious Education are separate concepts and activities in schooling. Schools in Ireland are still struggling to deconstruct centuries of practice whereby responsibility for children and young people's spiritual development is assigned to teachers and priests who have tended to rely on overly cognitive methods to the detriment of experiential approaches to spiritual development. However, the ongoing evolution of non-faith-based schools and greater awareness among teachers in the faith-based school of new pedagogies that can be used to promote spirituality among young people will hopefully contribute to a greater emphasis on spirituality education as a distinct activity within schools in Ireland.

\section{NOTES}

1. Its long title is "An Act to restrain Foreign Education”.

\section{REFERENCES}

Bauman, Z. (1991). Modernity and ambivalence. Ithaca, NY: Cornell University Press.

Boldt, S. (2000). A vantage point of values-Findings from school culture and ethos questionnaires. In C. Furlong \& L. Monahan (Eds.), School Culture and Ethos. Dublin: Marino.

Coolahan, J., Hussey, C., \& Kilfeather, F. (2012). The Forum on Patronage and Pluralism in the Primary Sector. Dublin: Department of Education and Skills.

Cooper, B. (2010). Empathy, interaction and caring: Teachers' roles in a constrained environment. Journal of Pastoral Care in Education, 22(3), 12-21.

Coyle, G. L. (1947). Group experience and democratic values. New York: Women's Press.

Corish, P. J., The Catholic community in the seventeenth and eighteenth centuries, (Dublin: Catholic Historical Society of Ireland, 1981).

Department of Education, (1965). Rule for Primary Schools. Dublin: Stationery Office.

de Souza, M., \& McLean, K. (2012). Bullying and violence: Changing an act of disconnectedness into an act of kindness. Pastoral Care in Education: An International Journal of Personal, Social and Emotional Development, Special Edition, 30(2), 165-180.

Dewey, J. (1916/1966). Democracy and education. New York: The Free Press.

Drumm, M. (1997). Symposium The future of religion in Irish education. In P. Hogan \& K. Williams (Eds.), The future of religion in Irish education (pp.108127). Dublin: Veritas.

Dunn, Seamus., 'Education, religion and cultural change in the Republic of Ireland', in Christianity and Educational Provision in International Perspective, ed. by W. Tulasiewicz and C. Brock (London: Routledge, 1988), pp. 87-99. 
Essau, C.A., Karpinski, N.A., Petermann, F. \& Conradt, J. (1998). Häufigkeit und Komorbidität psychischer Störungen bei Jugendlichen: Ergebnisse der Bremer Jugendstudie. Zeitschrift für Klinische Psychologie, Psychiatrie und Psychotherapie, 46, 105-124.

Fombonne, E. (1998). Increased rates of psychosocial disorders in youth. European Archives of Psychiatry and Clinical Neuroscience, 248, 14-21.

Freire, P. (1993). Pedagogy of the oppressed. New York: Continuum.

Glendenning, Dympna, (2007). Education and the Law. West Sussex: Tottel.

Government of Ireland, (1998). Education Act. Dublin: Government Publications.

Government of Ireland, (1999). Primary School Curriculum. Dublin: Government Publications.

Hanafin,S., Brooks, A., Macken, A., Brady, G., McKeever, R., Judge, C., Ryan, B., ... Gavin,A. (2008). State of the nation's children. Dublin: Department of Health and Children, Office for the Minister for Children and Youth Affairs.

Hyland, Aine and Milne, Kenneth., (eds) Irish Educational Documents, Vol. 1, (Dublin: Church of Ireland, College of Education, 1987).

Lindeman, E. C. (1926). The meaning of adult education. New York: New Republic. Republished in a new edition in 1989 by The Oklahoma Research Center for Continuing Professional and Higher Education.

Lynch, F. , Mills, C, Daly, I., and Fitzpatrick, C. (2006). Challenging times: Prevalence of psychiatric disorders and suicidal behaviours in Irish young persons. Journal of Adolescence, 29(4), 555-573.

Martin, M. (2006). School matters: Indiscipline in second level schools. Report of the National Task Force. Dublin. Government Publications.

McAleese, M. (2013). Report of the Inter-Departmental Committee to establish the facts of State involvement with the Magdalen Laundries. Dublin: Department of Justice and Equality.

McCracken, J. L., 'The ecclesiastical structure, 1714-1760' in A New History of Ireland. Eighteenth-Century Ireland 1691-1800, ed. by T. W. Moody and W. E. Vaughan (Oxford: 1986).

Miller, L., \& Athan, A. (2007). Spiritual awareness pedagogy: The classroom as spiritual reality. International Journal of Children's Spirituality, 12(1), 17-35.

Morrow V. (2000). Networks and neighbourhoods: Children's and young people's perspectives. London: Health Development Agency.

O’Higgins Norman, J., \& Hall, E. (2010). Violence and conflict in schools, negotiating pathways to well-being. In M. de Souza, L. Francis, J. O’Higgins Norman, $\&$ D. Scott (Eds.), International handbook of education for spirituality, care and wellbeing (pp. 1101-1114). Netherlands: Springer.

Pring, R. (2007). The common school. Journal of Philosophy of Education, 41(4), 503-522.

Puura, K., Almqvist, F., Tamminen, T., Piha, J., Räsänen, E., Kumpulainen, K., ... Koivisto A.-M. (1998). Psychiatric disturbances among prepubertal children in Southern Finland. Social Psychiatry and Psychiatric Epidemiology, 33(7), 310-318.

Raftery, D. (2009). The legacy of legislation and the pragmatics of policy: Historical perspectives on schooling for Irish children. In S. Drudy (Ed.), Education in Ireland: Challenge and change (pp. 9-23). Dublin: Gill \& Macmillan.

Van Roy, B., Grøholt B., Heyerdahl, S., and Clench-Aas J. (2006). Self-reported strengths and difficulties in a large Norwegian population 10-19 years. Age and gender specific results of the extended SDQ-questionnaire. European Child \& Young Person Psychiatry, 15(4), 1435-1465.

Watson, J. (2000). Whose model of spirituality should be used in the spiritual development of school children? International Journal of Children's Spirituality, 5(1), 91-101. 


\section{James O'Higgins Norman and Caroline Renehan}

1

2

3

4

5

6

7

8

9

10

11

12

13

14

15

16

17

18

19

20

21

22

23

24

25

26

27

28

29

30

31

32

33

34

35

36

37

38

39

40

41

42

43

44

45

46

Williams, K. (2007). Education and the voice of Michael Oakeshott. Exeter: Imprint Academic.

World Health Organisation Regional Office for Europe. (2007). Social cohesion for mental wellbeing among young persons. WHO/HBSC Forum Report. Copenhagen: World Health Organisation.

Zembylas, M. (2012). Pedagogies of strategic empathy: Navigating through the emotional complexities of anti-racism in higher education. Teaching in Higher Education, 17(2), 113-125. 